\title{
Correlation of overweight condition and obesity with mortality by COVID-19 in Brazil's state capitals
}

${ }^{1}$ Universidade Federal de Santa Catarina, Florianópolis, SC, Brasil
Correspondence to:

Danúbia Hillesheim

Programa de Pós-Graduação

em Saúde Coletiva,

Universidade Federal de

Santa Catarina

Campus Reitor João

David Ferreira Lima

Rua Delfino Conti, s/n. Bloco H

88040-900 - Florianópolis, SC, Brasil

nubiah12@yahoo.com.br

Received on Aug/9/2020

Accepted on Mar/2/2021

DOI: 10.20945/2359-3997000000351
Raquel Alencastro Veiga Domingues Carneiro ${ }^{1}$
https://orcid.org/0000-0002-0770-9771

Danúbia Hillesheim ${ }^{1}$

https://orcid.org/0000-0003-0600-4072

Ana Luiza Curi Hallal ${ }^{1}$

https://orcid.org/0000-0003-4761-0001

\begin{abstract}
Objective: To evaluate the correlation between the prevalence of overweight condition and obesity with mortality rates due to COVID-19 in Brazil's state capitals. Materials and methods: This is an ecological study, whose units of analysis were the 26 state capitals and the Federal District of Brazil. Prevalence was estimated by the results of the Vigilância de Fatores de Risco e Proteção para Doenças Crônicas por Inquérito Telefônico 2019 (VIGITEL). The general mortality rates due to COVID-19 were collected on the official website of the Brazilian Ministry of Health (MH) and stratified by the same Brazilian capitals evaluated in the VIGITEL survey. The rates included the period between the 1st and 29th Epidemiological Weeks of 2020. The Partial Correlation Test ( $r$ ) was used, controlled for confounding factors, to evaluate the correlation between the prevalence of overweight/obesity and the overall mortality rates due to COVID-19. Results: The mean mortality rate for COVID-19 in the period was 65.1 deaths per 100,000 inhabitants. Regarding the prevalence of obesity and overweight, $20.2 \%$ and $54.7 \%$ were the mean values observed in the state capitals, respectively. The prevalence of obesity was positively correlated with the overall mortality rate due to COVID-19, with mean positive correlation ( $r=0.380$ ) and statistically significant correlation $(p=0.034)$. Conclusion: This study pointed out that, at the aggregate level, there is a concomitant and correlated increase in mortality rates due to COVID-19 and prevalence of obesity in Brazilian capitals. The data found may contribute to actions to cope with the pandemic aimed at this population. Arch Endocrinol Metab. 2021;65(3):386-91
\end{abstract}

Keywords

Mortality; COVID-19; SARS-CoV-2; obesity; overweight

\section{INTRODUCTION}

$\mathrm{T}$ he first cases of pneumonia of unknown cause occurred at the end of 2019 in China (1). In January 2020, the etiological agent was identified and classified as Sars-CoV-2, a new species of Coronavirus (2) and, at the end of the same month, the World Health Organization (WHO) declared Coronavirus disease (COVID-19) a Public Health Emergency of International Importance (3). Brazil presented a mortality rate of 50.7 per 100,000 inhabitants until August 14, 2020, with important regional differences (4).

As research developed, more has been understood about the disease and its risk factors. COVID-19 was indicated to have worse prognosis and a higher risk of death when associated with obesity (5) and this condition has also been pointed out by several observational hospital-based studies (6-8) as an important factor associated with a worse prognosis for the infection. This association was also described for the SARS/MERS virus in previous publications, with indications of strong correlation between obesity and complications due to infection by other genetically similar to Sars-CoV-2 coronaviruses (5). Correlation with overweight condition was scarcely reported in the literature (6). To the day of this study, populationbased research in the matter was also scarce.

Additionally, the situation in Brazil regarding obesity and overweight condition rates and the pandemic require special attention, due to the fact that the prevalence of obesity and overweight are high in the country and have increased significantly over the years (9). Accordingly, if these findings are extended to a populational level, the healthcare system will have another challenge in face of the pandemic: a 
significant and increasing portion of the population at higher risk of worse COVID-19 infection outcomes. Better understanding of the matter could be crucial to guide public health policies and avoid an even heavier healthcare system burden.

Considering the scarcity of population-based studies, the fact that hospital-based studies are susceptible to selection bias, that overweight condition and obesity rates are of high magnitude in Brazil and the possible relationship between these factors and higher mortality due to COVID-19, the necessity of a populational analysis becomes clear to better understand this relation at an aggregate level, helping to delineate health policies.

Therefore, our research aimed to evaluate the correlation between the prevalence of overweight condition and obesity with mortality rates due to COVID-19 in Brazil's state capitals at an aggregate level.

\section{MATERIALS AND METHODS}

\section{Design and sample}

This is an ecological study in which the units of analysis were the 26 state capitals of Brazil and the Federal District, aiming to investigate the existence of correlation of overweight and obesity prevalence, in adults $(\geq 18)$, with general COVID-19 mortality rates. Data on prevalence, aggregate to capital level, for overweight condition, obesity and covariates were extracted from the Vigilancia de Fatores de Risco e Proteção para Doenças Crônicas por Inquérito Telefônico 2019 (VIGITEL - Surveillance of Risk and Protective Factors for Chronic Diseases) survey (10). The general mortality rates due to COVID-19 were collected from the official website of the Brazilian Ministry of Health $(\mathrm{MH})(4)$ and stratified by the same Brazilian capitals evaluated in the VIGITEL survey.

\section{Overweight and obesity data}

Both overweight and obesity prevalence were extracted from the results of the Vigilancia de Fatores de Risco e Proteção para Doenças Crônicas por Inquérito Telefônico 2019 (VIGITEL - Surveillance of Risk and Protective Factors for Chronic Diseases) survey. The VIGITEL is a population-based study which interviews adults $(\geq 18)$ who live in residences with landline telephones in all 26 state capitals and the Federal District of Brazil and aims to understand this population's health in order to guide programs and actions that reduce the occurrence of chronic diseases. The VIGITEL's sampling methodology allows to compare capital cities risk factor and protection estimates, between adult inhabitants. Detailed information on the sampling and data collection process was previously described (10). The Body Mass Index (BMI) is the parameter used by VIGITEL to determine overweight condition and obesity cutoffs and is calculated by dividing weight in kilograms by the height in square meters - both weight and height are self-reported within the survey. An individual with a BMI $\geq 25 \mathrm{~kg} / \mathrm{m}^{2}$ was considered to be overweight and individuals with BMI $\geq 30 \mathrm{~kg} / \mathrm{m}^{2}$ were considered to have obesity. It is worth noting that overweight condition, within VIGITEL, is a broader measure which also includes obesity $\left(\mathrm{BMI} \geq 30 \mathrm{~kg} / \mathrm{m}^{2}\right)$, whereas obesity is a narrower concept.

\section{COVID-19 mortality data}

General mortality rates due to COVID-19, during the period between the 1st and 29th Epidemiological Week of 2020 (11), were collected from the official website of the Brazilian Ministry of Health (MH). Mortality rates in the website were calculated by multiplying the number of confirmed COVID-19 deaths of resident population - TCU's (Tribunal de Contas da União) 2019 estimated population for FPM's (Fundo de Participação dos Municípios) quotas (12) - by 100.000 (4). The process of updating data on cases and deaths confirmed by COVID-19 in Brazil was carried out daily by the Ministry of Health, through official information provided by the State Health Secretariats of the 27 Brazilian Federative Units (4). Data was stratified by Brazilian capital cities, but they are not discriminated by age, socioeconomic condition or sex.

\section{Covariates}

The prevalence of diabetes mellitus (DM), systemic arterial hypertension $(\mathrm{SAH})$ and smoking were selected as covariates, since they were previously described as risk factors for COVID-19 infection (13). All prevalence was obtained from the VIGITEL 2019 survey as well. We considered, in this study, the VIGITEL's estimated prevalence of diabetes mellitus and systemic arterial hypertension assessed by personal statement of whether a diagnosis was already established by a doctor, regardless of treatment. These variables were collected through the questions: "Has any doctor ever told you 
that you have diabetes?" and "Has any doctor ever told you that you have high blood pressure?". The individual who answered positively to the question "Do you currently smoke?" was considered a smoker, regardless of number of cigarettes, frequency and duration of the smoking habit.

\section{Analysis}

The data were represented by means with standard deviation (SD), medians, minimum and maximum values. The graphical representation was made using a scatter plot. The variables obesity, overweight and mortality due to COVID-19 were also stratified by Brazilian capitals. We used the Partial Correlation Test ( $\mathrm{r}$ ), controlled for confounding factors, to evaluate the correlation between the prevalence of overweight/obesity and the overall mortality rates due to COVID-19. The use of correlation tests between similar measures was previously described (14). This technique was chosen because it allows the evaluation of the pure relationship between two variables, after statistically eliminating the influence of other independent variables. Cohen's parameters (15) were used for the interpretation of correlation values $(r)$ : between 0.10 and 0.29 to indicate a non-existent or small correlation, between 0.30 and 0.49 to indicate that there is a mean correlation and between 0.50 and 1 to indicate a large correlation. Data was analyzed with the program IBM $\left(\right.$ SPSS $\left.^{\circledR}\right)$ version 25 . The variables $\mathrm{DM}, \mathrm{SAH}$ and smoking were used as control variables. The significance level adopted was $5 \%(\mathrm{p}<0.05)$.

\section{Ethical aspects}

The VIGITEL was approved by the National Committee of Ethicsin Research.(CAAE: 65610017.1.0000.0008). The mortality rates due to COVID-19 are available for public access, without the identification of participants and its use exempt approval of the Ethics Committee, according to resolution no. 510, of April 7, 2016, of the National Health Council.

\section{RESULTS}

The mean mortality rate due to COVID-19 was 65.1 deaths per 100,000 inhabitants in Brazil's state capitals, with a minimum coefficient of 6.9/100,000 in Campo Grande (MS) and a maximum of $135.5 / 100,000$ in Belém (PA). Regarding the prevalence of obesity and overweight, averages of $20.2 \%$ and $54.7 \%$ were observed in these state capitals, respectively (Table 1).

Table 1. Description of mortality rates, prevalence of obesity and overweight according to Brazilian capitals and description of the mean, median, minimum and maximum values of the study's covariates. Capital cities of Brazil

\begin{tabular}{|c|c|c|c|}
\hline $\begin{array}{l}\text { Brazilian } \\
\text { capitals }\end{array}$ & $\begin{array}{c}\text { COVID-19 } \\
\text { mortality rate* }\end{array}$ & Obesity & Overweight \\
\hline Aracaju & 69.1 & 20.6 & 53.6 \\
\hline Belém & 135.5 & 19.6 & 53.3 \\
\hline Belo Horizonte & 13.6 & 19.9 & 52.5 \\
\hline Boa Vista & 85.9 & 21.2 & 54.3 \\
\hline Campo Grande & 6.9 & 22.5 & 58 \\
\hline Cuiabá & 69.5 & 22.5 & 55.8 \\
\hline Curitiba & 18.4 & 19.4 & 53.7 \\
\hline Florianópolis & 7.6 & 17.8 & 53.6 \\
\hline Fortaleza & 134.3 & 19.9 & 55.6 \\
\hline Goiânia & 20.4 & 19.5 & 52.7 \\
\hline João Pessoa & 64.0 & 20.4 & 54.7 \\
\hline Macapá & 64.4 & 22.9 & 53.3 \\
\hline Maceió & 65.9 & 20 & 54.4 \\
\hline Manaus & 89.9 & 23.4 & 60.9 \\
\hline Natal & 75.0 & 22.5 & 56.6 \\
\hline Palmas & 9.4 & 15.4 & 49.9 \\
\hline Porto Alegre & 13.7 & 21.6 & 59.2 \\
\hline Porto Velho & 85.9 & 19.9 & 56.6 \\
\hline Recife & 123.7 & 21.7 & 59.5 \\
\hline Rio Branco & 75.9 & 23.3 & 56.6 \\
\hline Rio de Janeiro & 114.6 & 21.7 & 57.1 \\
\hline Salvador & 53.6 & 18.1 & 51.8 \\
\hline São Luís & 96.1 & 17.2 & 50.3 \\
\hline São Paulo & 71.6 & 19.9 & 55.8 \\
\hline Teresina & 68.6 & 17.6 & 52.7 \\
\hline Vitória & 88.7 & 17.6 & 49.1 \\
\hline Distrito Federal & 36.0 & 19.6 & 55 \\
\hline Mean (SD) & $65.1(38.8)$ & $20.2(2.0)$ & $54.7(2.8)$ \\
\hline Median & 69.1 & 19.9 & 54.4 \\
\hline Minimum & 6.9 & 15.4 & 49.1 \\
\hline \multirow[t]{2}{*}{ Maximum } & 135.5 & 23.4 & 60.9 \\
\hline & $\begin{array}{l}\text { Diabetes } \\
\text { Mellitus }\end{array}$ & $\begin{array}{c}\text { Systemic } \\
\text { Arterial } \\
\text { Hypertension }\end{array}$ & Smoking \\
\hline Mean (SD) & $6.8(1.1)$ & $23.3(3.4)$ & $8.3(2.7)$ \\
\hline Median & 6.8 & 24.3 & 7.9 \\
\hline Minimum & 4.6 & 16.9 & 4.4 \\
\hline Maximum & 8.6 & 28.5 & 14.6 \\
\hline
\end{tabular}

Weighted prevalence (VIGITEL. 2019).

* Estimated for every 100.000 inhabitants. 
Figure $\mathrm{l}$ shows the dispersion graph between the prevalence of obesity (a), overweight (b) and the mortality rates due to COVID-19 in Brazilian capitals. Visually, a greater slope of the line is observed between the prevalence of obesity and mortality due to COVID-19.

The prevalence of obesity was positively correlated with the overall mortality rate due to COVID-19, with statistically significant $(\mathrm{p}=0.034)$ and mean positive correlation $(\mathrm{r}=0.380)$. Although no statistical significance was evidenced, we also observed a mean positive correlation $(\mathrm{r}=0.367)$ between COVID-19 mortality rate and overweight (Table 2).

Table 2. Correlation between overweight and obesity (2019) and mortality rates due to COVID-19 (2020) in the capital cities of Brazil

\begin{tabular}{lcc}
\hline \multirow{2}{*}{ Variables } & \multicolumn{2}{c}{ COVID-19 mortality rate } \\
\cline { 2 - 3 } & $\mathbf{r}^{\star}$ & $\mathbf{p}$-value \\
\hline Overweight & 0.367 & 0.078 \\
Obesity & 0.380 & 0.034 \\
\hline
\end{tabular}

r: Partial Correlation coefficient.

${ }^{*}$ Correlation adjusted for diabetes, hypertension and smoking variables.

(a)

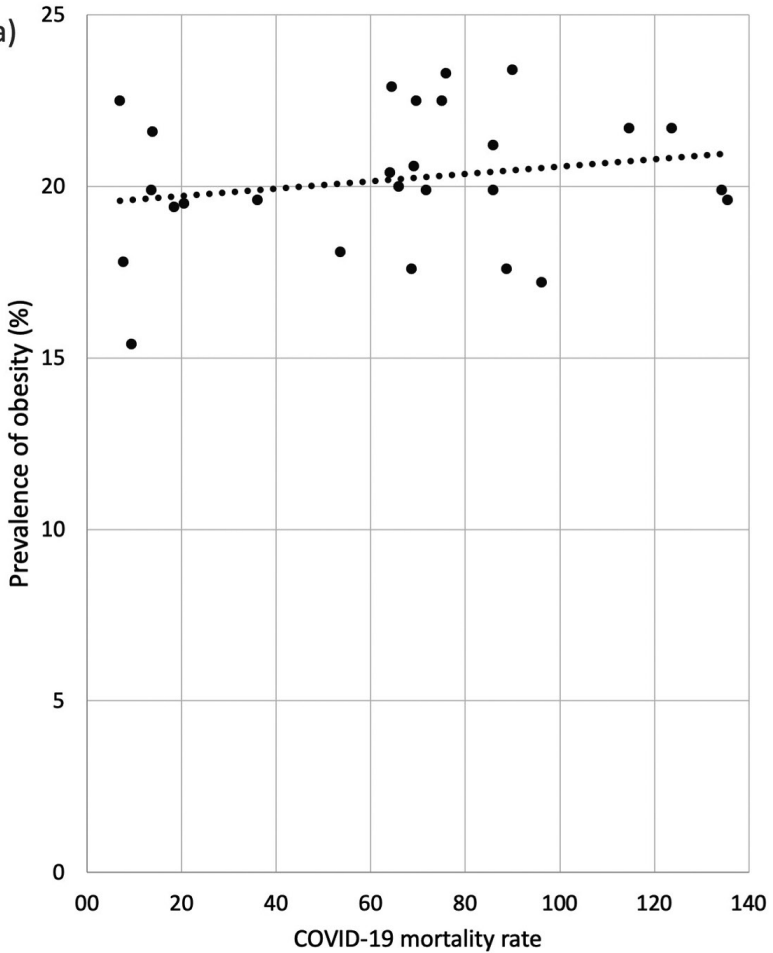

\section{DISCUSSION}

Corroborating our findings, prospective and hospitalbased articles found an association between obesity and progression to the severe form of COVID-19 infection $(6,7)$, obesity as a risk factor for mortality $(8,16)$ and longer hospital stay for these patients $(17)$. Moreover, Palaiodimos and cols. (18) reported that severe obesity is independently associated with a worse prognosis and mortality. Although the underlying mechanisms are still unclear, literature has indicated potential reasons why obesity may be a risk factor for severe COVID-19 infection and higher mortality: the presence of uncontrolled chronic obesity-related comorbidities (19), impaired pulmonary function, elevated angiotensin-converting enzyme 2 (ACE2) expression (20), chronic inflammation (13), oxidative stress and lipotoxicity (5). Cardiac damage, aggravated inflammatory response and increased coagulation activity were correlated to mortality amongst patients with obesity (16). Furthermore, evidence has shown that obesity has been linked to increased susceptibility to infections in general $(5)$.

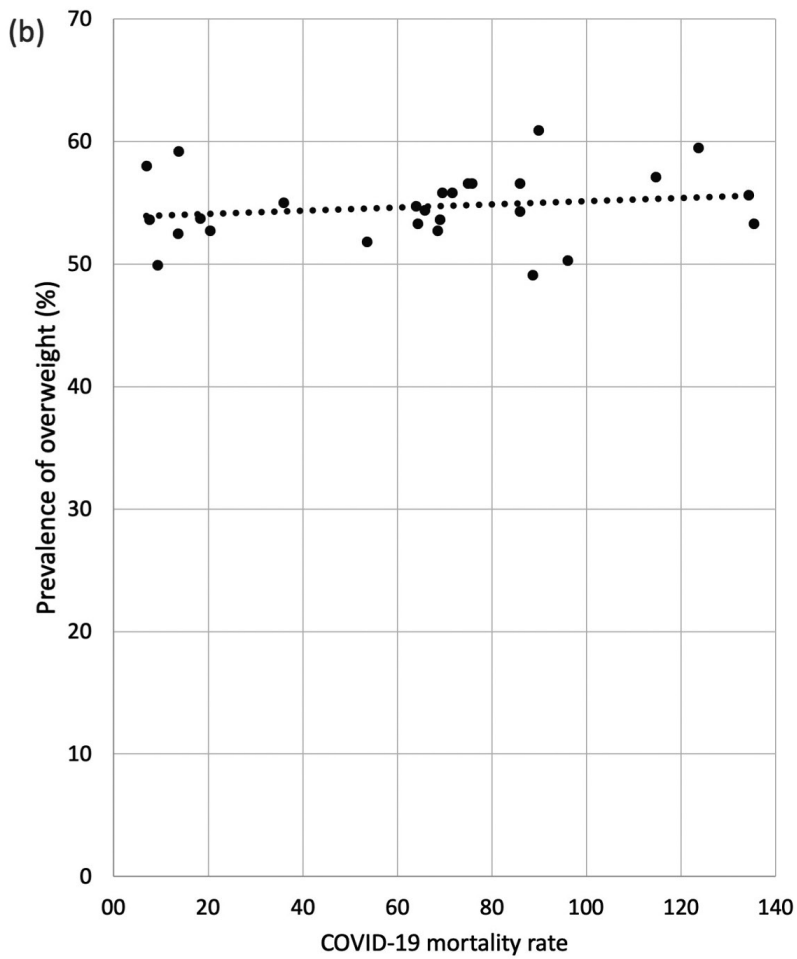

Figure 1. (A) Scatter plot between prevalence of obesity and mortality rates by COVID-19; (B) Scatter plot between prevalence of overweight and mortality rates by COVID-19. Capital cities of Brazil. 
Regarding overweight condition, this study did not verify a population-level correlation between overweight and mortality due to COVID-19 and literature on the matter is scarce (6). In Brazil general overweight and obesity rates have increased with time and the situation is challenging. The country has a national strategic plan that aims to combat non transmissible chronic diseases (Plano de Ações Estratégicas para o Enfrentamento de Doenças Crônicas Não Transmissíveis) (21), and one of its purposes is to halt the growth of both overweight and obesity rates. The VIGITEL survey - which supplies the aforementioned plan - shows that, from 2006 to 2019 , overweight and obesity rates increased from $42.6 \%$ to $55.4 \%$ and $11.8 \%$ to $20.3 \%$, respectively (10). In face of a pandemic this data is particularly concerning because of the possible impacts to the National Healthcare System (SUS - Sistema Único de Saude) in terms of occupation, expenditure and availability - since an expressive portion of brazilian population may be at higher risk of worse prognosis. Greater understanding of how COVID-19 may impact people with overweight condition and obesity at a populational level - the aim of this study - is of great importance to delineate Healthcare strategies and public policies, preventing and preparing for potential worsened scenarios.

Limitations of this study must be considered when interpreting the results. Two secondary data sources were included in this study, one (VIGITEL) is a population-based survey and the other is a mortality rate information system (Brazilian Ministry of Health (MH) website). Vigitel (10) is based on the interviewees' report, which may have led to information bias. However, researchers attest to the validity of this strategy, demonstrating high sensitivity (> 91\%) and specificity $(>83 \%)$ values for BMI, calculated via selfreported height and weight (22). Also, the source of information used to verify deaths due to COVID-19 is influenced by the testing capacity of the capital cities observed, as well as by the ability to notify and monitor epidemiological surveillance of each site, with recognized underreporting of cases and deaths (23) and important regional differences (4). It is important to highlight though that the mortality rates information system in Brazil evolves in terms of quality and coverage, generating reliable data for research (24).

In addition, an important limitation concerns variables such as age, socioeconomic condition and sex. The prevalence measures used here refer to resident adults aged 18 years or older, whereas the mortality rate refers to all resident individuals, since the database does not discriminate rates by age. Therefore, although deaths due to COVID-19 mostly occur among adults (25), this fact may have influenced the observed results. Equally important, socioeconomic condition and sex variables couldn't be evaluated due to the same database restrictions. In order to evaluate these factors, other sources would have to be included in the analysis, compromising comparability and interfering in the results' heterogeneity. Therefore, VIGITEL and the HM website were added as the only sources.

Moreover, the epidemiological design itself is susceptible to aggregation bias or ecological fallacy, therefore, the relationship observed between variables at the aggregate level may not be valid at the individual level - although, as mentioned before, hospital-based prospective studies results were consistent with our findings.

We were able to conduct a population based study that, to the best of our knowledge, is the first investigation addressing the relationship between prevalence of overweight condition and obesity with mortality rates due to COVID-19 nationwide. In conclusion, our results showed that, at aggregate level, there is a concomitant and correlated increase in mortality rates due to COVID-19 and prevalence of obesity in Brazilian capitals. Additional studies are needed to confirm and expand our results. Better understanding in this matter, especially at a population level, is crucial in order to support focused public policies.

Individual collaboration of each author in the preparation of the manuscript: Raquel Alencastro Veiga Domingues Carneiro contributed to the study design, writing and revision of the final article. Danúbia Hillesheim contributed to the study design, data analysis and interpretation, writing and reviewing the final article. Ana Luiza Curi Hallal contributed to the conception and design of the study, writing and final review of the article.

Funding source: the study did not have funding.

Disclosure: no potential conflict of interest relevant to this article was reported.

\section{REFERENCES}

1. Lu H, Stratton C, Tang Y. Outbreak of pneumonia of unknown etiology in Wuhan, China: The mystery and the miracle. J Med Virol. 2020;92(4):401-2. 
2. Zhu N, Zhang D, Wang W, Li X, Yang B, Song J, et al. A Novel Coronavirus from Patients with Pneumonia in China, 2019. N. Engl. J. Med. 2020;382(1):727-33.

3. World Health Organization. WHO Director-General's statement on IHR Emergency Committee on Novel Coronavirus (2019-nCoV). Geneva:WHO; 2020.

4. Brasil. Ministério da Saúde (MS). Painel Coronavírus. Access on: Aug. 1, 2020. Available from: https://covid.saude.gov.br/.

5. Petrakis D, Margină D, Tsarouhas K, Tekos F, Stan M, Nikitovic D, et al. Obesity - a risk factor for increased COVID-19 prevalence, severity and lethality (Review). Mol Med Rep. 2020;22(1):9-19.

6. Cai $\mathrm{Q}$, Chen F, Wang T, Luo F, Liu X, Wu Q, et al. Obesity and COVID-19 Severity in a Designated Hospital in Shenzhen, China. Diabetes Care. 2020 Jul;43(7):1392-8.

7. Hajifathalian K, Kumar S, Newberry C, Shah S, Fortune B, Krisko $T$, et al. Obesity is associated with worse outcomes in COVID-19: Analysis of Early Data From New York City. Obesity. 2020;28(9):1606-12.

8. Pettit NN, MacKenzie EL, Ridgway JP, Pursell K, Ash D, Patel B, et al. Obesity is Associated with Increased Risk for Mortality Among Hospitalized Patients with COVID-19. Obesity (Silver Spring). 2020 Oct;28(10):1806-10.

9. Malta DC, Andrade SC, Claro RM, Bernal RT, Monteiro CA. Trends in prevalence of overweight and obesity in adults in 26 Brazilian state capitals and the Federal District from 2006 to 2012. Rev Bras Epidemiol. 2014;17 Suppl 1:267-76.

10. Brasil. Vigitel 2019. Ministério da Saúde, Secretaria de Vigilância em Saúde, Departamento de Análise em Saúde e Vigilância de Doenças não Transmissíveis. Brasília: Ministério da Saúde, 2020. 137. Available from: http://bvsms.saude.gov.br/bvs/publicacoes/ vigitel_brasil_2019_vigilancia_fatores_risco.pdf

11. Brasil. SINAN - Calendário Epidemiológico de 2020. Available from: http://portalsinan.saude.gov.br/calendarioepidemiologico-2020.

12. Brasil. Ministério da Saúde. Datasus. População residente do Brasil. Access on: Jan 13, 2021. Available from: https://datasus. saude.gov.br/populacao-residente/.

13. Chiappetta S, Sharma A, Bottino V, Stier C. COVID-19 and the role of chronic inflammation in patients with obesity. Int J Obes. 2020;44(8):1790-2.

14. Amann V, Santos L, Gigante D. Associação entre excesso de peso e obesidade e mortalidade em capitais brasileiras e províncias argentinas. Cad Saúde Pública. 2019;35(12).1-13.

15. Cohen J. Statistical power analysis for the behavioral sciences. 1988. Hillsdale, NJ, Erlbaum.
16. Zhang F, Xiong Y, Wei Y, Hu Y, Wang F, Li G, Liu K, Du R, Wang CY, Zhu W. Obesity predisposes to the risk of higher mortality in young COVID-19 patients. J Med Virol. 2020;92(11):2536-42.

17. Moriconi D, Masi S, Rebelos E, Virdis A, Manca ML, De Marco $\mathrm{S}$, Taddei S, Nannipieri M. Obesity prolongs the hospital stay in patients affected by COVID-19, and may impact on SARS-COV-2 shedding. Obes Res Clin Pract. 2020;14(3):205-9.

18. Palaiodimos L, Kokkinidis D, Li W, Karamanis D, Ognibene J, Arora $\mathrm{S}$, et al. Severe obesity, increasing age and male sex are independently associated with worse in-hospital outcomes, and higher in-hospital mortality, in a cohort of patients with COVID-19 in the Bronx, New York. Metabolism. 2020(1);108:154262.

19. Valerio A, Nisoli E, Rossi AP, Pellegrini M, Todesco T, El Ghoch M. Obesity and Higher Risk for Severe Complications of Covid-19: What to do when the two pandemics meet. J Popul Ther Clin Pharmacol. 2020;27(S Pt 1):e31-e36.

20. Sanchis-Gomar F, Lavie CJ, Mehra MR, Henry BM, Lippi G. Obesity and Outcomes in COVID-19: When an Epidemic and Pandemic Collide. Mayo Clin Proc. 2020 Jul;95(7):1445-53.

21. Brasil. Ministério da Saúde. Secretaria de Vigilância em Saúde. Departamento de Análise de Situação de Saúde. Plano de ações estratégicas para o enfrentamento das doenças crônicas não transmissíveis (DCNT) no Brasil 2011-2022/Ministério da Saúde. Secretaria de Vigilância em Saúde. Departamento de Análise de Situação de Saúde. - Brasília: Ministério da Saúde, 2011. 160 p.

22. Carvalho AM, Piovezan LG, Selem SS, Fisberg RM, Marchioni DM. Validation and calibration of self-reported weight and height from individuals in the city of São Paulo. Rev Bras Epidemiol. 2014;17(3):735-46.

23. Hallal P, Hartwig F, Horta B, Victora G, Silveira M, Struchiner C, et al. Remarkable variability in SARS-CoV-2 antibodies across Brazilian regions: nationwide serological household survey in 27 states. Preprint. 2020. doi: https://doi.org/10.1101/2020.05.30.20117531

24. Souza ACM, Neto DLR. Avaliação da qualidade dos dados sobre mortalidade no Brasil de 2000 a 2016. 378-392. Cap. 18. 2019 In: Brasil. Ministério da Saúde. Saúde Brasil 2018 uma análise de situação de saúde e das doenças e agravos crônicos: desafios e perspectivas/Ministério da Saúde, Secretaria de Vigilância em Saúde, Departamento de Vigilância de Doenças e Agravos Não Transmissíveis e Promoção da Saúde - Brasília: Ministério da Saúde, 2019. 424 p.

25. Fu L, Wang B, Yuan T, Chen X, Ao Y, Fitzpatrick T, et al. Clinical characteristics of coronavirus disease 2019 (COVID-19) in China: A systematic review and meta-analysis. J Infect. 2020;80(6):656-65. 